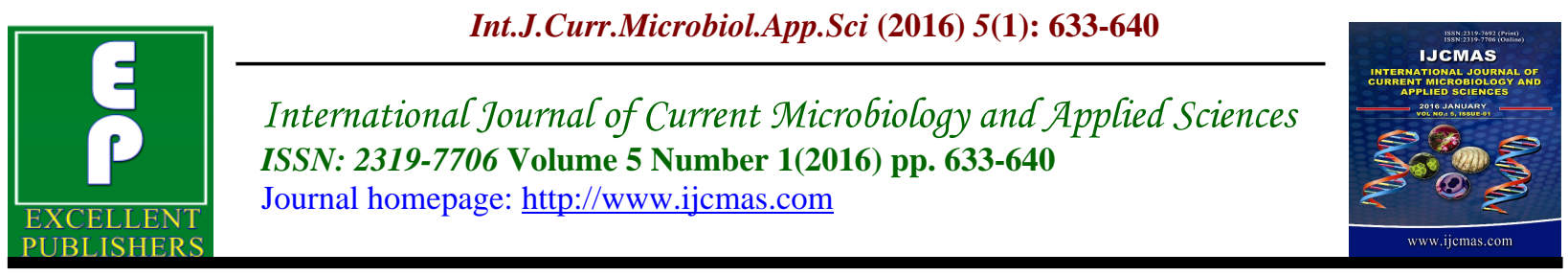

Original Research Article

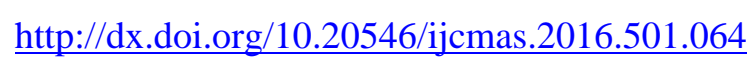

\title{
Qualitative and Quantitative Phytochemical analysis of Moringa concanensis Nimmo
}

\author{
K. Santhi and R. Sengottuvel* \\ Department of Botany, Arignar Anna Government Arts College, Namakkal-637 002, \\ Tamil Nadu, India \\ *Corresponding author
}

\section{Introduction}

The evaluation of all the drugs is based on phytochemical and pharmacological approaches which leads to the drug discovery referred as natural product screening (Foye et al., 2008). Any part of the plant may contain active components such as bark, leaves, flowers, roots, fruits and seeds (Gordon and David, 2001).

Phytochemicals are the chemicals produces by various parts of the plants. These bioactive constituents of plants are steroids, terpenoids, carotenoids, flavanoids, alkaloids, tannins and glycosides.
These compounds have various activities such as antimicrobial and antibacterial some have been reported to exhibit heamolytic and foaming activity reported by Feroz et al. (1993).

Number of various environmental factors such as climate, altitude, rainfall and other conditions may affect growth of plants which in turn affect the quality of herbal ingredients present in a particular species even when it is produced in the same country. These conditions may produce major variations in the bioactive compounds 
present in the plants (Kokate et al., 2004). Qualitative phytochemical screening will help to understand a variety of chemical compounds produced by plants and quantification of those metabolites will help to extract, purify and identify the bioactive compounds for useful aspects to human beings.

Plants have limitless ability to synthesize aromatic substances, mostly phenols or their oxygen-substituted derivatives (Geisssman, 1963). Most of the natural products are secondary metabolites and about 12,000 of such products have been isolated so far. These products serve as plant defence mechanisms against predation by microorganisms, insects and herbivores (Fransworth and Morris, 1976). Today there is growing interest in chemical composition of plant based medicines. Several bioactive constituents have been isolated and studied for pharmacological activities. During the last two decades, the pharmaceutical industry has made massive investment in pharmacological and chemical researches all over the world in an effort to discover much more potent drugs, rather, a few new drugs. Plants have successfully passed the tests of commercial screenings.

Furthermore, the use of herbal medicine for the treatment of diseases and infections is as old as mankind. The World Health Organization supports the use traditional medicine provided they are proven to be efficacious and safe (WHO, 1985). In developing countries, a huge number of people lives in extreme poverty and some are suffering and dying for want of safe water and medicine, they have no alternative for primary health care. There is therefore the need to look inwards to search for herbal medicinal plants with the aim of validating the ethno-medicinal use and subsequently the isolation and characterization of compounds which will be added to the potential list of drugs.

Moringa concanensis is a medicinal plant belonging to the family Moringaceae (Fig.1). It is present in large amount in the Tamil Nadu state, India. M. concanensis is widely distributed on dry lands of Tamil Nadu. M. concanensis is an evergreen tree with a spreading crown, up to 7-8 feet. Leaves alternate, 2-3- pinnate, obovate, caducous. Flowers large, white, hermaphrodite, irregular in axillary panicles. Calyx thinly tomentose, long, segments white, oblong, reflexed. Petals yellow, veined with red, oblong. Stamens 5fertile and 4-5 staminodes. Capsule straight, actively triquetrous, slightly contsricted between the seeds. Seeds white or pale yellow 3- angled. The present investigation to find out the qualitative and quantitative analysis from the leaves, flowers and seeds.

\section{Materials and Methods}

\section{Selection of Plant Species}

The plant materials (Leaves, flowers and seeds) of $M$. concanensis were collected from the Kunnam of Perambalur District, Tamil Nadu(Fig.2). The plant materials were washed thoroughly 2-3 times with running tap water and once sterile with distilled water. Then the plant parts were shade dried and coarsely powdered separately and stored in well closed bottles for further analysis in laboratory.

\section{Authentication of Plant Materials}

The plant was authenticated at The Rapinet Herbarium, St.Joseph's College, Tiruchirappalli, Tamil Nadu and Botanical Survey of India [BSI], Southern Circle, Coimbatore. India. The specimen was labelled, numbered and annotated with the 
date of collection and locality.

\section{Extraction of the Plant Materials}

The fresh plant materials were washed with running tap water and shade dried. The leaves, flowers and seeds were crushed to coarsely powdered. These coarse powders $(25 \mathrm{~g})$ were then subjected to successive extraction in $250 \mathrm{ml}$ of methanol solvent by using Soxhlet apparatus. The collected extracts were stored and then used for further analysis. The DMSO (Dimethyl sufloxide) is act as dissolved solvents for these extracts.

\section{Qualitative Phytochemical Analysis}

Preliminary phytochemical analysis was carried out for the extract as per standard methods described by Brain and Turner (1975) and Evans (1996).

\section{Detection of Alkaloids}

Extracts were dissolved individually in dilute hydrochloric acid and filtered. The filtrates were used to test the presence of alkaloids.

Mayer's test: Filtrates were treated with Mayer's reagent. Formation of a yellow cream precipitate indicates the presence of alkaloids.

Wagner's test: Filtrates were treated with Wagner's reagent. Formation of brown/ reddish brown precipitate indicates the presence of alkaloids.

\section{Detection of Flavonoids}

Lead acetate test: Extracts were treated with few drops of lead acetate solution. Formation of yellow colour precipitate indicates that the presence of flavonoids.
$\mathrm{H}_{2} \mathrm{SO}_{4}$ test: Extracts were treated with few drops of $\mathrm{H}_{2} \mathrm{SO}_{4}$. Formation of orange colour indicates that the presence of flavonoids.

\section{Detection of Steroids}

Two $\mathrm{ml}$ of acetic anhydride was added to five $\mathrm{mg}$ of the extracts, each with two $\mathrm{ml}$ of $\mathrm{H}_{2} \mathrm{SO}_{4}$. The colour was changed from violet to blue or green in some samples indicate that the presence of steroids.

\section{Detection of Terpenoids}

\section{Salkowski's Test}

Five mg of the extract of the leaves, flowers and seeds was mixed with two $\mathrm{ml}$ of chloroform and concentrated $\mathrm{H}_{2} \mathrm{SO}_{4}(3 \mathrm{ml})$ was carefully added to form a layer. An appearance of reddish brown colour in the inner face was indicates that the presence of terpenoids.

\section{Detection of Anthroquinones}

\section{Borntrager's Test}

About five mg of the extract was boiled with $10 \% \mathrm{HCl}$ for few minutes in a water bath. It was filtered and allowed to cool. Equal volume of $\mathrm{CHCl}_{3}$ was added to the filtrate. Few drops of $10 \% \mathrm{NH}_{3}$ were added to the mixture and heated. Formation of pink colour indicates that the presence anthroquinones.

\section{Detection of Phenols}

Ferric chloride test: $10 \mathrm{mg}$ extracts were treated with few drops of ferric chloride solution. Formation of bluish black colour indicates that the presence of phenol.

Lead acetate test: $10 \mathrm{mg}$ extracts was treated with few drops of lead acetate 
solution. Formation of yellow colour precipitate indicates that the presence of phenol.

\section{Detection of Saponins}

About $0.5 \mathrm{mg}$ of the extract was shaken with five $\mathrm{ml}$ of distilled water. Formation of frothing (appearance of creamy miss of small bubbles) shows that the presence of saponins.

\section{Detection of Tannins}

A small quantity of extract was mixed with water and heated on a water bath. The mixture was filtered and ferric chloride was added to the filtrate. A dark green colour was formed. It indicates that the presence of tannins.

\section{Detection of Carbohydrates}

$0.5 \mathrm{mg}$ extracts were dissolved individually in five $\mathrm{ml}$ distilled water and filtered. The filtrate was used to test the presence of carbohydrates.

\section{Detection of Protein \& Amino acids}

Biuret test: To $0.5 \mathrm{mg}$ of extract equal volume of $40 \% \mathrm{NaoH}$ solution and two drops of one percent copper sulphate solution was added. The appearance of violet colour indicates that the presence of protein.

Ninhydrin test: About $0.5 \mathrm{mg}$ of extract was taken and two drops of freshly prepared $0.2 \%$ Ninhydrin reagent was added and heated. The appearance of pink or purple colour indicates that the presence of proteins, peptides or amino acids.

\section{Detection of Oils and Resins}

Test solution was applied on filter paper. It develops a transparent appearance on the filter paper.

It indicates that the presence of oils and resins.

\section{Quantitative Phytochemical analysis}

\section{Estimation of Alkaloids}

Alkaloid determination by using Harborne (1973) method. One gram of the sample was weighed into a $250 \mathrm{ml}$ beaker and $200 \mathrm{ml}$ of $10 \%$ acetic acid in ethanol was added and its covered and allowed to stand for $4 \mathrm{~h}$. It was filtered and the extract was concentrated on a water bath to one quarter of the original volume. Concentrated $\mathrm{NH}_{4} \mathrm{OH}$ was added by drop wise to the extract until the precipitation was complete. The whole solution was allowed to settle and the precipitate was collected and washed with dilute $\mathrm{NH}_{4} \mathrm{OH}$ and then filtered. The residue is the alkaloid, which was dried and weighed.

\section{Estimation of Flavonoids}

One grams of plant sample was repeatedly extracted with $100 \mathrm{ml}$ of $80 \%$ aqueous methanol at room temperature. The mixture was filtered through a Whatman No1 filter paper into a pre-weighed $250 \mathrm{ml}$ beaker. The filtrate was transferred into a water bath and allowed to evaporate to dryness and weighed.(Krishnaiah et al., 2009).

\section{Estimation of Total Phenols}

The fat free sample was boiled with $50 \mathrm{ml}$ of ether for the extraction of the phenolic component for $15 \mathrm{~min}$. Five $\mathrm{ml}$ of the extract was pipetted out into a $50 \mathrm{ml}$ flask, then $10 \mathrm{ml}$ of distilled water was added. Two $\mathrm{ml}$ of $\mathrm{NH}_{4} \mathrm{OH}$ solution and $5 \mathrm{ml}$ of concentrated amyl alcohol were also added. 
The samples were made up to mark and left to react for $30 \mathrm{~min}$ for colour development. This was read at $505 \mathrm{~nm}$.

\section{Estimation of Carbohydrate}

$100 \mathrm{mg}$ of sample was hydrolysed in a boiling tube with $5 \mathrm{ml}$ of $2.5 \mathrm{~N} \mathrm{HCl}$ in a boiling water bath for a period of 3 hours. It was cooled at room temperature and solid sodium carbonate was added until effervescence ceases. The contents were centrifuged and the supernatant was made to $100 \mathrm{ml}$ by using distilled water. From this $0.2 \mathrm{ml}$ of sample was pipetted out and made up the volume to one $\mathrm{ml}$ with distilled water. Then one $\mathrm{ml}$ of phenol reagent was added and followed by $5.0 \mathrm{ml}$ of sulphuric acid. The tubes were kept at $25-30^{\circ} \mathrm{C}$ for $20 \mathrm{~min}$. The absorbance was read at $490 \mathrm{~nm}$ (Krishnaveni et al., 1984).

\section{Results and Discussion}

The present study was carried out on the $M$. concanensis revealed that the presence of active phytochemical constituents. The phytochemical active compounds of $M$. concanensis were qualitative and quantitatively analysed from leaves, flowers and seeds separately and the results are mentioned in Table 1 and Table 2 respectively.

The quantitative estimation of primary metabolites revealed that the various phytochemical constituents present in the plant extract (Table-2). In seed sample of $M$. concanensis, the alkaloid content was $2.15(\mathrm{~W} / \mathrm{w})$, flavonoids content was $10.08(\mathrm{~W} / \mathrm{w})$, phenol content was not detected and the carbohydrate content was about 5.86(W/w). But in the case of flower sample the alkaloids content found to be 4.37(W/w), flavonoids content was 15.12(W/w), phenol content was
$30.18(\mathrm{~W} / \mathrm{w})$ and carbohydrate about $7.49(\mathrm{~W} / \mathrm{w})$. Finally the leaf sample contains the alkaloid content about $5.92(\mathrm{~W} / \mathrm{w})$, the flavonoid content was $15.74(\mathrm{~W} / \mathrm{w})$, phenol content $37.52(\mathrm{~W} / \mathrm{w})$ was very higher than the other two sample and finally the carbohydrate contents was found to be 9.15(W/w).

Fig.1 Moringa concanensis Nimmo- Habit

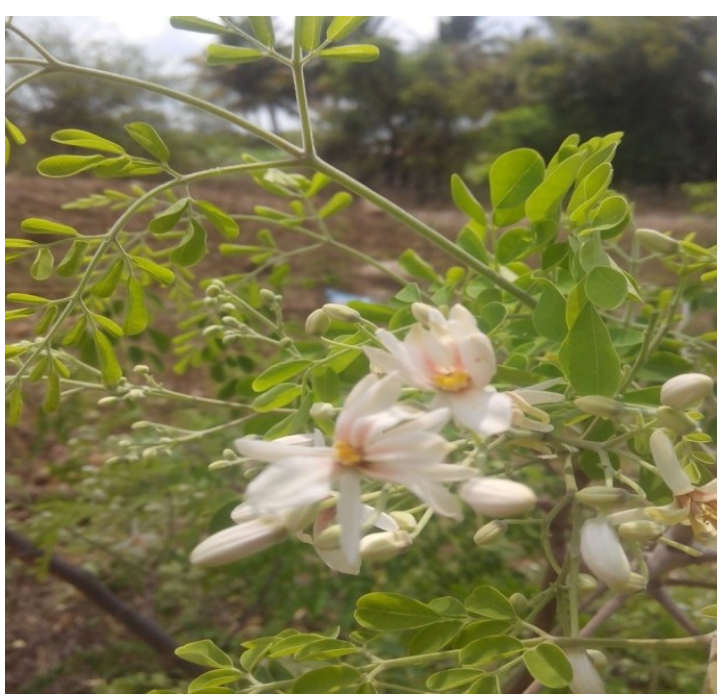

Fig.2 Perambalur District-Map

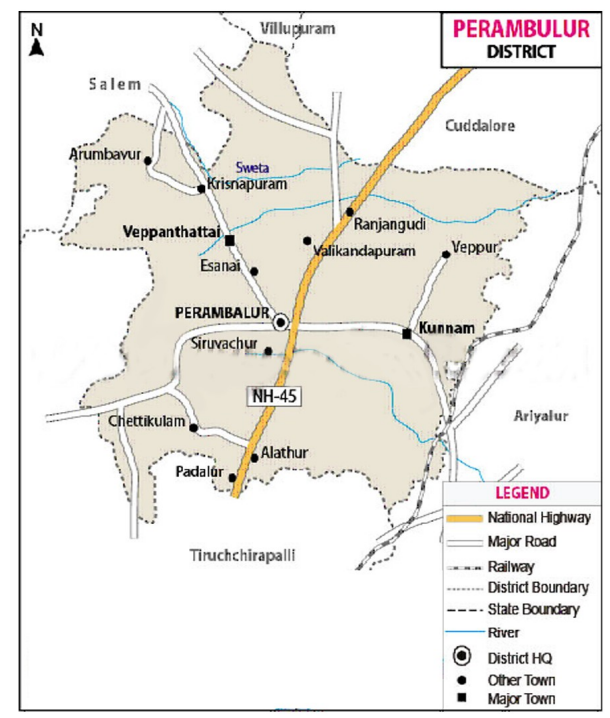


Table.1 Qualitative Phytochemical Analysis of M. concanensis Leaves, Flowers and Seeds Extracted with Methanol Solvent

\begin{tabular}{|c|c|c|c|}
\hline \multirow{2}{*}{ Phytochemicals } & \multicolumn{3}{|c|}{ Methanol Extracts } \\
\hline & Leaves & Flowers & Seeds \\
\hline $\begin{array}{l}\text { Alkaloids } \\
\text { Mayer's test } \\
\text { Wagner's test } \\
\end{array}$ & $\begin{array}{l}+ \\
+\end{array}$ & $\begin{array}{l}+ \\
+ \\
+\end{array}$ & $\begin{array}{l}+ \\
+\end{array}$ \\
\hline $\begin{array}{l}\text { Flavonoids } \\
\text { Lead acetate test } \\
\mathrm{H}_{2} \mathrm{SO}_{4} \text { test }\end{array}$ & $\begin{array}{l}+ \\
+\end{array}$ & $\begin{array}{l}+ \\
+\end{array}$ & $\begin{array}{l}+ \\
+\end{array}$ \\
\hline $\begin{array}{l}\text { Steroids } \\
\text { Liebermann-Burchard test }\end{array}$ & - & - & - \\
\hline $\begin{array}{l}\text { Terpenoids } \\
\text { Salkowski test }\end{array}$ & + & + & + \\
\hline $\begin{array}{l}\text { Arthroquinone } \\
\text { Borntrager's test }\end{array}$ & - & - & - \\
\hline $\begin{array}{l}\text { Phenols } \\
\text { Ferric chloride test } \\
\text { Lead acetate test }\end{array}$ & $\begin{array}{l}+ \\
+\end{array}$ & $\begin{array}{l}+ \\
+\end{array}$ & - \\
\hline Saponin & + & + & - \\
\hline Tannin & - & - & - \\
\hline Carbohydrates & + & + & + \\
\hline $\begin{array}{l}\text { Proteins \& Amino acids } \\
\text { Biuret test } \\
\text { Ninhydrin test } \\
\end{array}$ & $\begin{array}{l}+ \\
+\end{array}$ & $\begin{array}{l}+ \\
+\end{array}$ & $\begin{array}{l}+ \\
+\end{array}$ \\
\hline Oils \& Resins & - & - & - \\
\hline
\end{tabular}

(+) Present (-)Not detected

Table.2 Quantitative Phytochemical Analysis of M.Concanensis Leaves,Flowers and Seeds Extracted with Methanol Solvent

\begin{tabular}{|c|l|c|c|c|}
\hline S.No & Phytochemicals & Leaves $(\mathbf{W} / \mathbf{w})$ & Flowers $(\mathbf{W} / \mathbf{w})$ & Seeds $(\mathbf{W} / \mathbf{w})$ \\
\hline 1 & Alkaloids & 5.92 & 4.37 & 2.15 \\
\hline 2 & Flavonoids & 15.74 & 15.12 & 10.08 \\
\hline 3 & Phenol & 37.52 & 30.18 & - \\
\hline 4 & Carbohydrates & 9.15 & 7.49 & 5.86 \\
\hline
\end{tabular}

The present investigation shows that significant variation in the contents like alkaloids, flavonoids, phenol and carbohydrate when compared to above mentioned results. These variations are due to number of environmental factors such as climate, altitude, rainfall etc. as mentioned (Kokate et al., 2004). Saponins act as antimicrobial activity and extremely to coldblooded animals,but toxicity to mammals is low (Sneh verma et al., 2013). Saponins are a mild detergent used in intracellular histochemistry staining to allow antibody access to intracellular proteins. The saponins are used in hypercholestrolaemia, hyperglycemia, antioxidant, anticancer, anti 
inflammatory activity and weight loss (Manickam murugan et al., 2014).

The phytochemical screening of flowers and flower buds are not been reported earlier although flower and flower buds of M.concanensis also help in abortion and leucorrhea (Anbazhakan et al., 2007). Alkaloids have been used as both antibacterial and antidiabetic properties and useful for such activities. Phenols and phenolic compounds have been extensively used in disinfections and remain the standard with which other bacterisides are compared (Akinyeye et al., 2014).

In the present study conclude that the $M$. concanensis leaves have the potential to act as a source of useful drugs because of presence of various phytochemical constituents such as alkaloids, flavonoids, phenol, terpenoids, saponin and carbohydrates. These phyto constituents seemed to be the potential to act as a source of useful drugs and also to improve the health status of the consumers as a result of the presence of various compounds that are vital role for good health.

\section{Acknowledgement}

It should be acknowledge, The Head Dept. of Botany, The Principal, Arignar Anna Government Arts College, Namakkal-2. For providing laboratory facilities to carryout the work.

\section{References}

Akinyeye, A.J., E.O. Solanke and I.O. Adebiyi, 2014. Phytochemical and antimicrobial evaluation of leaf and seed of Moringa olifera extracts. Int. J. of Res. In Med. and Health Sciences., 4(6): 2307-2083.

Anbazhakan, S., R. Dhandapani.,
P.Anandhakumar and S. Balu, 2007. Traditional medicinal knowledge on Moringa concanensis Nimmo of perambalur District, Tamilnadu, Anc. Sci. of life., 24(4): 42-45.

Brain, K.R., and T.D. Turner, 1975. The practical evaluation of phytopharmaceuticals, Wrightscience technical, $1^{\text {st }} \mathrm{Ed}$, Bristol Britain., 144.

Evans, W.C., 1966. Trease Evans Pharmacognosy., $14^{\text {th }}$ Ed, London: WB Saunders Ltd, 119 159.

Feroz, M., R. Ahmad., S.T.A.K. Sindhu and A.M. Shahbaz, 1993. Antifungal activities of saponin from indigenous plant roots. Pak. Vet. J., 13: 44

Foye, W.O., T.L. Lemke and D.A. Williams, 2008. Foye's Principles of Medicinal Chemistry. 6th Ed Lippincott Williams and Wilkins. Philadelphiap., 44-45.

Fransworth, N.R., and R.W. Morris, 1976. Higher plants, The sleeping Giant of Drug Development. Am. J. Pharm., 148: 46-52.

Geisssman, T.A., 1963. Flavonoid compounds, Tannins, Lignins and related compounds, In $M$.

Florkin and Stotz (Ed), Pyrrole Pigments, Isoprenoid compounds and phenolic plant constituents Vol. 9. 265.

Gordon, M.C., and J.N. David, 2001. Natural product drug discovery in the next millennium. Pharm. Biol. 39 Suppl., 1: 8-17.

Grieve, M., 1931. A Modern Herbal. New York: Dover Publications.

Harbone, J.B., 1973. Phytochemical methods. London. Chapman and Hall, Ltd., 49-188.

Jain, S.K., 1989. Methods and Approaches in Ethnobotany, (Ed) Society of 
Ethnobotanists, CDRI.

Lucknow.

Kokate, C.K., Purohit, A.P., and Gokhale, S.B. 2004. Practical Pharmacognosy, 2nd edition. Vallabh Prakashan, New Delhi, 466470.

Krishnaiah, D., T. Devi, A. Bono and R. Sarbatly, 2009. Studies on phytochemical constituents of six Malaysian medicinal plants. $J$. Med. Plants. Res. 3(2): 67-72.

Krishnaveni, S., B. Theymoli., S. Sadasivam, 1984. Phenol Sulphuric acid method. Food chain., 15: 229.
Manickam murugan., Veerabahu Ramasamy Mohan, 2014. Phytochemical, FT-IR and antibacterial activity of whole plant extract of Aerva lanata (L.) Juss. Ex. Schult. J. of Med. Plants Studies, 2(3): 51-57.

Sneh verma., Tandra Mohan., T. Revathy., K. Suthindhiran and M.A. Jayasri, 2013. Phytochemical and pharmacological evaluation of selected plants. Am. J. of Biochem. and Biotechnol, 9(3): 291-299.

World Health Organization, 1985. Chronicle., 39:51.

\section{How to cite this article:}

K. Santhi and R. Sengottuvel. 2016. Qualitative and Quantitative Phytochemical analysis of Moringa concanensis Nimmo. Int.J.Curr.Microbiol.App.Sci.5(1): 633-640 hittp://dx.doi.org/10.20546/ijcmas.2016.501.064 